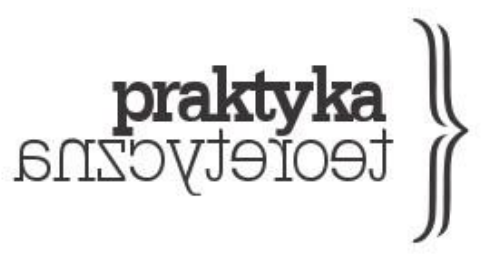

ISSN 2081-8130

DOI: $10.14746 /$ prt.2018.2.1 www.praktykateoretyczna.pl

\title{
DOKĄD ZMIERZA MATERIALIZM? ALTHUSSER/DARWIN
}

\author{
CATHERINE MALABOU
}

PRZEŁOŻYŁA: EWA WOJCIECHOWSKA

\begin{abstract}
Abstrakt: Autorka wykorzystuje Althusserowską koncepcję materializmu spotkania do rewizji darwinizmu oraz przemyślenia relacji między doborem w przestrzeni naturalnej i społecznej. W potocznym rozumieniu dobór społeczny zwany też społecznym darwinizmem opiera się na wyobrażeniu o rzeczywistości międzyludzkiej jako przestrzeni ciagłej walki i rywalizacji. W istocie nie ma on nic wspólnego z natura, argumentuje Malabou, to samoutwierdzający się mechanizm władzy, który dyscyplinuje i eliminuje możliwość zaistnienia różnicy w systemie. Ta klisza pomija przygodność i ateleologiczny charakter doboru oraz „stan plastyczny” organizmów w teorii Darwina. Właśnie owych plastyczności i przygodności brakuje nam dziś w rzeczywistości społecznej.
\end{abstract}

Słowa kluczowe: materializm, Darwin, Althusser, dobór społeczny, plastyczność, forma. 
Dokąd zmierza materializm? Ta fraza przypomina „Dokąd zmierza marksizm?”, tytuł konferencji zorganizowanej w 1993 w Kalifornii, podczas której Derrida wygłosił wykładową wersję Widm Marksa. Odnosząc się do dwuznaczności tytułu, Derrida zasugerował, że za „pytaniem »dokąd zmierza marksizm?« kryje się tė̇ inne, »czy marksizm umiera?«"1 (Derrida 2015, 7; przekład zmodyfikowany).

Ta sama dwuznaczność będzie przepracowywana w tym rozdziale ${ }^{2}$. Dokąd zmierza dziś materializm? Czy umiera? Pytania te pozwola mi oczywiście odnieść się do marksizmu, ale z punktu widzenia materializmu wypartego przez marksizm. Zgodnie z tym dziwnym ujęciem marksizmu, którego broni późny Althusser w fascynującym tekście „Podziemny nurt materializmu spotkania" (1982), we wszystkich dziełach Marksa oficjalny materializm wypierał swoją odmienną, skrytą wersję. Althusser odkrywa, że:

$[\ldots]$ istnieje pewna, niemal całkowicie zapoznana tradycja materialistyczna $[\ldots]$ : materializm spotkania, czyli materializm tego, co przypadkowe [aléatoire] i przygodne, [który] okazuje się myślą całkiem odmienną, czy wręcz przeciwstawną wobec innych materializmów, także wobec tego, który nagminnie imputuje się Marksowi, Engelsowi i Leninowi i który, jak cała tradycja racjonalistyczna, pozostaje materializmem konieczności i teleologii, to jest niczym innym, jak przekształconą i przebraną formą idealizmu (Althusser 2016, 38)3.

Chcę przeanalizować ów wyparty materializm, zagrażający konieczności, porządkowi, przyczynowości, znaczeniu; „niebezpieczny” materializm, jak opisuje go Althusser, który i to jest centralna koncepcja niniejszego artykułu - „zaczyna od niczego”. Co to znaczy zaczynać od niczego i czy to w ogóle jest możliwe?

Ponownie zacytuję Althussera: „Wyzwolić ów stłumiony materializm spotkania, odkryć, co wnosi on zarówno do filozofii, jak do samego materializmu, rozpoznać ukryte

1 Malabou odwołuje się tu do nieprzetłumaczalnej gry słów między podobnymi w brzmieniu whither (dokąd) oraz wither (zamierać, usychać). Wszystkie przypisy pochodzą od tłumaczki.

2 Prezentowany tekst stanowi rozdział pracy zbiorowej zatytułowanej Plastic Materialities: Politics, Legality, and Metamorphosis in the Work of Catherine Malabou pod redakcja B. Bhandar i J. Goldberga-Hillera (2015, Durham NC: Duke University Press).

3 Przywołany tu przekład nie obejmuje dalszej części wywodu Althussera, który stanowić miał rozdział 12 planowanej, a nieskończonej przez filozofa książki. Te fragmenty są zaś przez Malabou traktowane jako integralny element tekstu (autorka cytuje wydanie: Louis Althusser. 2006. Pbilosophy of the Encounter Later Writings, 1978-1987. Red. F. Matheron, O. Corpet. Tłum. G.M.G. Oshgarian. London-New York: Verso). Dlatego tam, gdzie jest to możliwe, powołuję się na tłumaczenie Jędrzeja Brzezińskiego, zaś w przypadkach, gdzie Malabou cytuje fragmenty z rozdziału 12, proponuję przekład własny. 
skutki jego pracy tam, gdzie oddziałuje w sposób milczący: oto zadanie, jakie chciałbym sobie postawić" (Althusser 2016, 39).

To zadanie stanowi oczywiście odpowiedź na pierwsze pytanie: dokąd zmierza materializm? Jednocześnie Althusser stawia kolejne: czy materializm spotkania wciąż jest materializmem? Czy odkrycie wypartego nie jest zawsze końcem tego, co odkryte? Czy materializm nie obumrze $\mathrm{w}$ tej przygodnej formie $\mathrm{i}$ w nicości, która zakłada? Czy przetrze nowe szlaki, czy zginie?

Chcę pokazać, że te dwa pytania są filozoficznie i politycznie ważne oraz bardzo aktualne.

A dlaczego Darwin? Na liście autorów, których Althusser uważa za reprezentantów nowego materializmu, znajduja się Epikur, Machiavelli, Spinoza, Hobbes, Rousseau, Nietzsche, Heidegger, Derrida, Deleuze, (pewien) Marks oraz Darwin. Dlaczego Darwin? Czy to arbitralny wybór? W pewnym stopniu tak, musi być arbitralny, skoro tylko przygodność odpowiada przygodności, a więc niech będzie Darwin. I w pewnym stopniu - nie. Spotkanie Althussera i Darwina, do którego tu doprowadzę, pomoże lepiej usytuować problem, który wnosi samo pojęcie spotkania. Łączy ich wiele: wizja niczego, nicości jako dziwnego ontologicznego punktu wyjścia, krytyka teleologii, idea doboru, słowem, ten sam materializm. Darwin materialista? Tak, według Althussera Darwin jest materialista spotkania.

Nim przejdę dalej, kilka definicji. Materializm to określenie dotyczące nietranscendentalnego statusu formy w ogóle. Materia jest tym, co formuje się w trakcie wytwarzania warunków możliwości swojego formowania się. Każda transcendentalna instancja z konieczności znajduje się na zewnątrz tego, co organizuje. Ze swej natury warunek możliwości jest odmienny od tego, co umożliwia. Materializm uznaje coś dokładnie odwrotnego: brak jakiegokolwiek zewnętrza dla procesu formowania. Samoformowanie I samoinformowanie się materii są systemowo nietranscendentalne.

Źródło tej immanentnej dynamiki można wyjaśnić dwojako. Pierwszą, dobrze znana wykładnia jest dialektyczna teleologia, gdzie formowanie się form - form życia, myśli, społeczeństwa - jest zarządzane przez wewnętrzne napięcie dążące do celu, który koniecznie determinuje każdy samorozwój. Althusser odrzuca tę dominująca, teleologiczną wizję materializmu, który zakłada, że „wszystko jest już dokonane, struktura poprzedza poszczególne elementy i reprodukuje je, by reprodukować strukturę" (Althusser 2006, 200). To podejście sprowadza się w praktyce do analityki transcendentalnej, dlatego Althusser utożsamia je z idealizmem.

Materializm spotkania, przeciwnie, nie zakłada żadnego celu, racji czy przyczyny, a utrzymuje raczej, wbrew jakiejkolwiek transcendentalnej strukturze, „nie-uprzedniość Sensu" (Althusser 2016, 39). Z tej perspektywy formy to spotkania, które przyjęły formę. Althusser upiera się przy takim „przyjmowaniu formy” czy „ścinaniu się”, „tak jak wodę 
„»Ścina«" lód albo tak, jak „»ścina się»" mleko lub majonez” (Althusser 2016, 56)”. Formowania się formy należy doszukiwać się tu w tym, co „nadaje formę” rezultatom spotkania. Spotkanie musi „przyjąć formę” i „ściąć się”, by trwać i stać się koniecznym.

Wyjaśniając ten specyficzny rodzaj plastyczności - ścinanie się i przyjmowanie form z niczego - Althusser zwraca się do Darwina:

To znaczy, że zamiast myślenia przygodności jako modalności albo wyjątku od konieczności, należy myśleć konieczność jako stawanie się koniecznymi elementów przygodnych w spotkaniu. Widzimy zatem, że nie tylko świat życia (biolodzy, którzy powinni byli uważniej czytać Darwina, dopiero ostatnio zdali sobie z tego sprawę), ale także świat historii krzepnie wokół kilku szczęśliwych momentów tego »ujęcia« [prise], elementów w koniunkcji, której kształt wyznacza dane spotkanie: pewien gatunek, pewna jednostka, pewien lud (Althusser 2016, 58).

To właśnie przejście między gatunkiem, jednostką i ludem chcę tu zbadać. Czy te formy są równorzędne? Czy możemy przenieść to, co dzieje się na poziomie natury, na poziom polityki czy historii?

Po pierwsze, pytam o to, do jakiego stopnia dobór społeczny może zostać włączony w obręb doboru naturalnego, o którym pisze Darwin. Następnie przeanalizuję różnicę między naturalnym a społecznym i politycznym spotkaniem. Gdzie w społeczeństwie istnieje pustka, nicość, punkt zero, z którego może wyłonić się forma? W zakończeniu postaram się usytuować nową Althusserowską krytykę kapitalizmu w kontekście współczesnej filozofii I wyłaniających się dziś nowych materializmów.

II.

Słowo „plastyczność”, którego użyłam przed chwila do opisu procesu krzepnięcia formy w materializmie spotkania, nie było moim własnym wyborem. Wnikliwa lektura O powstawaniu gatunków wskazuje, że plastyczność stanowi jeden z kluczowych motywów myśli Darwina I znajduje się w samym sercu teorii ewolucji. Jak, według niego, „forma” przyjmuje formę? Koncepcja plastyczności pozwala wyartykułować - jak wskazuje Darwin na początku książki - fundamentalny związek między zmiennością jednostek w ramach gatunku a doborem naturalnym pomiędzy tymi jednostkami.

Najpierw zmienność. Bez niej nie ma gatunku. By odwołać się do terminologii Althussera, zmienność jest „pustką”, „punktem zero”, „nicością”, z której wyłaniaja się formy. Najważniejsza cechą gatunku jest podatność na mutacje: wielość potencjalnych transformacji morfologicznych, jakie można zaobserwować w strukturze organizmu, stanowi 
funkcję jego zdolności do zmieniania formy. Wbrew powszechnym, acz błędnym odczytaniom według Darwina gatunki nigdy nie są sztywne czy trwałe. Filiacja odsłania ogromną plastyczność gatunku: „Budowa całego organizmu staje się jakby plastyczna i powoli, nieznacznie oddala się od organizmu rodzicielskiego" (Darwin 2013, 13). Na początku rozdziału piątego Darwin pisze: „[...] układ rozrodczy jest szczególnie podatny na zmiany warunków życia; dlatego przede wszystkim zaburzeniom funkcjonalnym tego układu u rodziców przypisuję zmienny lub plastyczny stan potomstwa" (2013, 125). Zmienność, plastyczność desygnują quasi-nieskończoną możliwość zmian w strukturze, autoryzowaną przez samą żyjąca strukturę. Właśnie ta quasi-nieskończoność konstytuuje otwartość czy brak predeterminacji, które umożliwiają spotkanie.

Forma „krzepnie”, kiedy zmienność spotyka dobór naturalny, który przekształca jej przygodność w konieczność. „Jestem przekonany, że z tych wszystkich przyczyn zmian najważniejszą siłą jest skumulowane działanie doboru [...]” (Darwin 2013, 38).

Trzeba więc zrozumieć, że dobór kieruje zmiennością i reguluje formowanie się form. Dobór pozwala na przyjęcie formy zorientowanej, odpowiadającej naturalnym wymogom wydolności, ciagłości i autonomii jednostek. Stan plastyczny - motor ewolucji jako takiej - opiera się na plastyczności rozumianej, z jednej strony, jako płynność struktur, a z drugiej, jako wybór wydajnych, trwałych form, które moga być potem dziedziczone. Materializm spotkania odnosi się więc do naturalnego procesu zabezpieczającego ciagły dobór i krzepnięcie, krystalizowanie się zmienności.

Relacja między zmiennościa a doborem prowokuje fundamentalne filozoficzne pytanie, które chciałabym zadać Althusserowi. W naturze relacja między zmiennością a doborem nie jest, w sensie ścisłym, zaplanowana. Paradoksalnie dobór naturalny u Darwina wydaje się mechanizmem pozbawionym jakiejkolwiek intencji wyboru. Najlepsi sa najlepiej przystosowani, ale zdolność ta nie zależy od sądów wartościujących czy jakiejkolwiek teleologii.

Dobór naturalny jest, powtórzmy, spotkaniem: ateleologicznym, bez uprzednio założonych intencji. Tak długo, jak jest jedynie mechanizmem - termin ten ewokuje ślepy ruch, przeciwieństwo czy rewers wolności - dobór naturalny nie daje się przewidzieć, obiecuje formy, które nigdy nie zostały uprzednio wybrane, różnice, które nadejda.

To właśnie kluczowy problem: wydaje się, że naturalne formowanie się form nie może mieć przeznaczenia społecznego, o ile nie zostanie zamaskowane lub błędnie przedstawione. Znamy błąd „społecznego darwinizmu”, któremu daleko do filozofii plastyczności, bowiem sprowadza się do prostej teorii walki między silnymi a słabymi. Przez wiele lat, szczególnie we Francji, dobór naturalny rozumiano przede wszystkim jako nieskomplikowany proces eliminowania słabszych oraz życia jako bezlitosnej walki o władzę w każdej formie. Zdarza się nam również mylić darwinizm i maltuzjanizm, który, wbrew 
obszernym zastrzeżeniom na ten temat zamieszczonym w $O$ powstawaniu gatunków, definiuje dobór naturalny jako prostą ilościową dynamikę, zarządzaną przez stosunek liczby jednostek w populacji do dostępnych zasobów. Taka interpretacja jest absolutnie niedarwinowska I błędna.

Ale dlaczego takie błędne odczytania są w ogóle możliwe? Może dlatego, że materializm spotkania wydaje się nie do utrzymania na gruncie politycznym i społecznym, bo może pracować jedynie na poziomie atomów lub form życia, ale nigdy w odniesieniu do jednostek czy ludów? Automatyzm i nieteleologiczny charakter doboru naturalnego zdają się ginąć na poziomie doboru społecznego. Dlaczego - w logice egzaminów, konkursów, szczególnie w doborze zawodowym, w rozróżnianiu kandydatów na tle ich zdolności, kompetencji czy konkretnych umiejętności technicznych - doborowi zdaje się brakować plastyczności, rozumianej jako elastyczność i brak uprzednio założonej intencji? Dlaczego przez większość czasu dobór społeczny sprawia wrażenie, jakby był przewidywalnym, ustalonym procesem, prostą logiką konformizmu i reprodukcji, podczas gdy dobór naturalny jest otwarty na nieskończone możliwości?

Czy materializm spotkania nie był zawsze skazany na wyparcie przez materializm teleologii, uprzedniości znaczenia, presupozycji, predeterminacji?

Stan plastyczny, który opisuje Darwin, domaga się szczególnej artykulacji tożsamości i różnicy. Tożsamości, ponieważ jednostki wyselekcjonowane w ramach doboru są zdolne do reprodukcji, a tym samym do wpisania siebie w stabilność tożsamego, dającego się zidentyfikować typu. Różnicy, ponieważ ta tożsamość nie jest wcale sztywna i daje się uzyskać jedynie ze zmienności. Konkretna tożsamość jest produkowana przez odróżnianie się struktur i typów. Jednak w naturze istnieje automatyczna, ślepa równowaga tożsamości I różnicy, podczas gdy, jak się wydaje, w porządku społecznym tożsamość zawsze dominuje nad różnica i tym samym naturalna, pełna gracji równowaga zostaje zachwiana. Idea wyboru, jako oczywisty paradoks, także jest nieobecna w doborze naturalnym. W naturze dobór jest nieświadomy. Gdy tylko dobór staje się intencją doboru, gdy zakłada wcześniej zdefiniowane, zaprogramowane kryteria, gdy nie ma już naturalności ani spontaniczności w awansowaniu, kondycja plastyczna zostaje zagrożona, a nawet przestaje istnieć. Po raz kolejny mamy więc do czynienia z wypieraniem jednego materializmu przez drugi.

W naturze najlepiej przystosowany nigdy nie jest tym, który przypadkiem trafił na najlepsze środowisko do przeżycia. To po prostu kwestia „przystosowania swojej odpowiedzi do środowiska", by użyć sformułowania François Jacoba (Jacob 1973, 23). Adaptacja, zgodność między środowiskiem a zmiennością, może być nieprzewidywalna. Nic nie jest lepsze „samo w sobie”. Oczywiście Darwin opisał dobór naturalny jako pracę udoskonalania lub poprawiania, ale jego pojęcie „lepszego” nie ma w sobie żadnej ukrytej intencji. Darwin powstrzymywał się od mówienia o „postępie”, sam nigdy nie pojmował 
swojej teorii jako teorii „ewolucji”, bowiem ten termin ryzykownie konotowałby linearny progres, porównywalny do Lamarkistowskiego prawa złożoności. Ulepszanie, o którym mówi tu Darwin, nie jest podporządkowane finalizmowi. Forma tych okazów, które utrzymały się przy życiu, ich trwałość w czasie, zostały ukształtowane przez zniknięcie gorzej dostosowanych, przez powrót wyeliminowanych form do stanu nieorganicznego. Ujmując rzecz słowami Canguilhema, „śmierć jest ślepym rzeźbiarzem żywych form” (1994, 212). Tym samym nieożywione, poprzez negację, warunkuje sens czy projekt życia.

Czy należy więc uznać, że darwinizm zatrzymuje się tam, gdzie zaczyna się społeczeństwo i kultura, i że każde nadanie mu przeznaczenia społecznego zdradza go, czyli innymi słowy, zmienia go, przekształca, zakłamuje, redukując dobór do procesu reprodukcji tożsamości?

Czy nie możemy wyobrazić sobie, wbrew wszystkiemu, plastyczności stanu społecznego i odzyskać bogactwa zmienności oraz odstępstw od struktury w samym sercu kultury? Czy nie da się pomyśleć społecznej i politycznej równowagi pomiędzy zmiennością I doborem? $\mathrm{Na}$ co wskazuje nam dziś Darwin? $\mathrm{Na}$ co wskazuje Althusser? Według niego plastyczność taka jak biologiczna powinna zapanować także w porządku politycznym. To głęboki sens jego nowego materializmu. Powróćmy teraz do jednostek i ludów.

Althusser dochodzi do „przyjmowania formy” przez jednostkę, gdy mówi o Księciu Machiavellego. Oto polityczna wersja materializmu spotkania na poziomie jednostki: „[...] Machiavelli dochodzi do wniosku, że jedność może się zawiązać, o ile znajdzie się jakiś bezimienny człowiek [...]. Tak właśnie padają kości na stół, który sam jest pusty (Althusser 2016, 41-42; przekład zmodyfikowany).

Mamy tu pustkę, brak znaczenia, celu czy predeterminacji. Forma wyłoni się ze spotkania między losem - czyli de facto przygodnością - i cnotą księcia, czyli umiejętnością wybrania najlepszej opcji z tego, co oferuje mu fortuna, przy czym wybór dokonuje się bez takiej intencji. Tak jakby istniał naturalny, plastyczny balans między lwem a lisem, fortuną i cnota.

W ten sposób książę wewnętrznie podlega przekształceniom zachodzącym w obrębie tego drugiego, przypadkowego spotkania, spotkania lisa, z jednej strony, z lwem i człowiekiem z drugiej. To, że do spotkania tego może wcale nie dojść, nie znaczy, że nie może do niego dojść. By figura księcia mogła „wziąć się” [prenne] z tego spotkania, musi być ono trwałe, a „wziąć się” to przyjać formę, zostać instytucjonalnie uznanym za dobre i, jeśli to możliwe, być takim rzeczywiście, ale tylko pod absolutnym warunkiem, że książę potrafił będzie okazać swą niegodziwość, jeśli tylko zajdzie taka potrzeba (Althusser 2016, 42-43). 
Ale jak może istnieć, społecznie, taki bezimienny człowiek, zdolny zacząć od niczego, od bezimiennego miejsca, od nieteleologicznego formowania się form?

Problem staje się bardziej palący, gdy Althusser przechodzi do ludu czy wspólnoty w rozumieniu Rousseau. Rousseau podnosi następująca polityczną kwestię: do jakiego stopnia człowiek został „zmuszony do spotkań” (Althusser 2016, 51), gdy znajdował się w stanie natury, zmuszony do życia w społeczeństwie? Czy da się przekształcić ten narzucony I bezprawny stan rzeczy w prawowity? Czy da się odtworzyć warunki dla przygodnej I nieteleologicznej formy spotkania po tym, jak spotkanie to już się wydarzyło? Uplastycznić je retroaktywnie, „podn[ieść] pewną nieprawomocną (zwyczajowa) formę do rangi formy prawomocnej?" (Althusser 2016, 53). To, zdaniem Althussera, wiodace zagadnienie Umowy spotecrnej.

Odkryte i ponownie zakryte jest tu to, co stanowi bez wątpienia najgłębszą myśl Rousseau: ujęcie wszelkiej możliwej teorii historii od strony myślenia przygodności konieczności, jako wynikającej z konieczności przygodności (ta para pojęć może tu zbijać $\mathrm{z}$ tropu, a jednak ma kluczowe znaczenie) (Althusser 2016, 53).

Ponownie, gdzie jest pustka, puste miejsce, z którego można rozpocząć taką zmianę? „Do spotkania może dojść jedynie w politycznej pustce” (Althusser 2016, 43). Ale gdzie ona się znajduje i czym może być?

III.

Wydaje się, że w naszych społeczeństwach nie ma miejsca na pustkę. Spójrzmy na proces doboru społecznego - rozumianego na przykład jako sortowanie i wybieranie możliwości lub odpowiednich umiejętności w ramach egzaminów, konkursów czy rozmów kwalifikacyjnych - który natychmiast jawi się jako przeciwieństwo stanu plastycznego, przewodniego w ekonomii doboru naturalnego i jej nieznaczącego sensu.

Katalog zadań, zakres obowiązków, protokół z egzaminów są zawsze uprzednie wobec realnego spotkania ze zmiennością i różnorodnością kandydatów, a więc uniemożliwiają to, by różnice wyłoniły się same. Taki dobór nie może polegać na produkcji różnic, lecz przeciwnie, utrwala kryteria wyboru. A więc nie wygrywają najlepsi ani nawet nie ci, którzy najlepiej się dostosowuja, tylko najbardziej posłuszni. Zgoda ma pierwszeństwo przed wartością. Zapewniając trwanie i odnawianie się tego samego, dobór społeczny zapewnia zatem powrót socjologicznego ciężaru, ale nigdy nie zapewnia wyłonienia się jednostkowości z niczego. 
Marks w Prayczynku do krytyki heglowskiej filozofii prawa jako pierwszy potępił konserwatywny charakter społecznego doboru zdolności. Na przykładzie urzędników (,indywidualnych jednostek jako przedstawicieli funkcji państwa”) pokazał, że nikt nie oczekuje od nich żadnych szczególnych kompetencji poza odtwarzaniem ustalonego porządku (Marks 1973, 266). Hegel w Zasadach filozofii prawa pisze, że

[...] jednostki nie są uprawnione do prowadzenia spraw państwa z racji swego naturalnego modusu, lecz zgodnie z tym, jaką obiektywną wartość przedstawiaja. Zdolności, umiejętności, charakter należą do szczegółowości jednostki; musi ona być wychowana i musi otrzymać wykształcenie do wykonywania pewnej szczegółowej czynności (Hegel 1969, 424).

Jednak te zdolności, powiada Marks, nie są zdolnościami: żadna „technika” nie jest potrzebna do tego, by zostać urzędnikiem, nie potrzeba biegłości w żadnej dziedzinie prócz talentu posłuszeństwa, szacunku dla państwa oraz konformizmu.

Kolejną krytykę doboru społecznego przeprowadza Pierre Bourdieu, szczególnie w pracy Spadkobiercy, napisanej wspólnie z Jean-Claude’em Passeronem w 1964, w której autorzy analizuja klasową trajektorię studentów. Normy doboru, zawsze uprzednio zdefiniowane, tworzą rzeczywisty program i zbiegają się z czystym konformizmem narzucanym przez klasy dominujące, które ustalają kryteria „kulturowej prawowitości” [cultural legitimacy], będącej przede wszystkim ukrytą władzą społeczną. To funkcja społecznego odtwarzania reprodukcji kulturowej, ufundowana na „przywileju”, czyli z definicji - na kryterium doboru najsilniej określonym z góry.

Dobór społeczny ma na celu reprodukować porządek, przywileje i dominująca ideologię. Nigdy nie wybiera się zdolności do działania czy politycznej walki, ale zawsze te kompetencje, które wspierają ład. Kto z nas nigdy nie był wstrzą́śnięty niesprawiedliwościa tego porządkowania, sortowania, które nominuje tylko jednostki najbardziej uległe, nigdy najbardziej wyjątkowe, i w efekcie premiuje przeciętność, brak kompetencji oraz wąski umysł? Kto nigdy nie czul, że dobór społeczny to program, a nie obietnica i że morfologiczne transformacje społeczne koniec końców są jedynie agentami utrzymania status quo?

To prowokuje kolejne pytanie: czy cel doboru społecznego jest przesądzony? Czy też mógłby on, na płaszczyźnie polityki, połączyć się z plastycznością stanu naturalnego? Jak możemy zapewnić w polu wspólnoty i kultury równowage między zmiennością a doborem, przyszłość różnicy, obietnicę form nieoczekiwanych? 
IV.

Althusser ma pełną świadomość tych trudności, niewspółmierności między spotkaniem w porządku ontologicznym czy naturalnym a spotkaniem w sferze politycznej. Istnieje jedno rozwiązanie: wiedzieć, że kryteria nie są uprzednie wobec selekcji. Dla społeczeństwa oznaczałoby to odzyskanie stanu plastycznego. Problem zawsze dotyczy tego, jak uniknąć odgórnej identyfikacji różnicy, skoro dobór, wspierając porządek, zawsze ustala wartości, a przez to tworzy hierarchie i normy. Jak pomyśleć ewaluację, nieuniknioną w każdym doborze społecznym, nie pozbawiając jej nieokreśloności i wolności?

Jedynym filozofem, który jasno postawił to pytanie, jest Nietzsche, i to do niego, rozprawiwszy się z Machiavellim i Rousseau, odnosi się Althusser. Z pewnością nie po to, by potępić ideę doboru, który jest nieunikniony i ma swoje ontologiczne uzasadnienie: samo stawanie się jest niczym innym jak doborem. Nie zapominajmy powiedzenia Heraklita: „Albowiem najlepsi jedno wybierają zamiast wszystkiego, wiecznie płynącą sławę śmiertelnych. Zaś wielu obżartych jest jak bydlęta" (Mrówka 2004, 111). Stawanie się jest tak bogatym w różnice, że może dokonywać się jedynie poprzez wybór. Zadanie filozofii polega na wybieraniu, ponieważ wybiera różnice otwierane przez flux życia, porządkuje i interpretuje je. W Ecce homo Nietzsche pyta: „A po czymże poznaje się w zasadzie, czy ktoś jest udany?” (Nietzsche 2016,13). Co sprowadza się do pytania, „kto przybrał formę?”.

W Różnicy $i$ powtórzenin Deleuze, do którego również odwołuje się Althusser, pokazuje, że selekcja generuje własne kryteria w toku swego działania (Deleuze 1997, 406407). Tym samym staje się wrażliwa na prawomocność i wydolność swoich różnic. Różnica zostaje wybrana, w miarę jak się dokonuje, demonstrując swoją zdolność do powracania, czyli produkcji jakiegoś dziedzictwa czy tradycji. Tym samym na przykład dobra muzyka rodzi tradycje interpretacji, dobry tekst rodzi czytelników-dziedziców. Dobór powinien więc wydarzać się po tym, jak wyłoni się czy rozkwitnie różnica, tak samo jak zmienność poprzedza dobór naturalny.

Althusser dobrze rozumie, że „polityczna pustka”, w której „może dojść do spotkania” (Althusser 2016, 43), jednocześnie jest „pustką filozoficzna” i może w ogóle nie istnieć; jeśli bylibyśmy pewni jej istnienia, jeśli wiedzielibyśmy o niej uprzednio, spotkanie nigdy nie miałoby miejsca, a my popadalibyśmy na powrót w teleologię. Określenie tej pustki nicości, tego punktu możliwości, który otwiera wszystkie obietnice sprawiedliwości, równości, praworządności, nie może być założone z góry ani regulowane w sposób ślepy I automatyczny, jak ma to miejsce w naturze. Należy je umożliwić. To jest właśnie zadanie filozoficzne, które pojawia się na końcu owego wypartego materializmu. 
Książę Machiavellego to według Althussera „[c]złowiek z niczym, zaczynający znikąd, z jakiegoś niedającego się ustalić miejsca" (Althusser 2016, 42). Znaleźć i nadać formę temu niedającemu się ustalić miejscu - oto co musimy zrobić. Niedające się ustalić [unassignable $^{4}$ to tłumaczenie francuskiego inassignable, ale nie jestem pewna, czy to słowo znaczy dokładnie to samo w obydwu jezzykach. Po francusku oznacza niezdeterminowane i nieskończone, po angielsku zaś - takie, które nie może zostać odrzucone i zamienione na coś innego: niezbywalne. Ale także nieprzypisane, nieprzeznaczone na konkretny cel. Angielski termin jest więc dużo ciekawszy, ponieważ otwiera w idei własności przestrzeń czegoś, co nie może zostać przypisane komuś innemu, co nie może zostać zanegowane bez zniszczenia podmiotu, co nie przynależy do nikogo i nie ma żadnego przeznaczenia. Możemy nazwać to miejsce, miejsce niedające się ustalić, właściwie anonimowym. Bez właściwości, bez przywilejów, bez dziedzictw, bez tradycji. Ludzie niczego, ludzie bohaterscy. Stąd i tylko stąd moga wyłaniać się nowe formy - jednostkowe, nieprzewidywalne, odrodzone, mówi Althusser.

Zanim zadamy kolejne pytania o to „miejsce”, zobaczmy, w jaki sposób nowy materializm wpływa na Althusserowską lekturę Marksa i jego krytykę kapitalizmu. W świetle tego nowego materializmu, jak pisze Althusser, Marks „zmuszony [był] myśleć w perspektywie rozdarcia między przypadkowością Spotkania i koniecznością Rewolucji”' (2016, 53), stąd wszystkie jego filozoficzne zdrady. W skrócie:

\begin{abstract}
W wielu passusach Marks [...] wyjaśnia, że kapitalistyczny tryb produkcji wynika ze spotkania między właścicielami pieniędzy a proletariuszami ogołoconymi ze wszystkiego prócz siły roboczej. Gdy to spotkanie się wydarza, przybiera formę, czyli trwa i staje się stanem dokonanym, opiera się o ustalone relacje i prawa, prawa rozwoju i kapitalistycznego trybu produkcji (Althusser 2006, 197).
\end{abstract}

Tak więc pierwotnie Marks analizuje ukonstytuowanie się kapitalizmu jako spotkania, zaczynając od plastycznej pustki, nicości proletariatu, jego fundamentalnego wywłaszczenia. Ale Marks i Engels nie pozostaja wierni tej wizji - wizji sposobu produkcji jako formy formującej się z niczego, agregującej różne elementy i stopniowo stającej się konieczną. Odwracają oni ten proces, potwierdzając ostatecznie, że przeznaczeniem różnych elementów konstytutywnych spotkania było od zawsze „znalezienie się w układzie, współgranie ze sobą, uzupełnianie się i wytwarzanie nawzajem swoich efektów i warunków” (Althusser 2006, 198). Marks i Engels zastępują analizę produkcji proletariatu analizą jego reprodukcji.

\footnotetext{
4 Język polski zmusza tu do tłumaczenia opisowego: wybieram zwrot wskazany przez tłumacza tekstu Althussera. Ewentualnie można by tu mówić o miejscu „niedającym się wyznaczyć lub przydzielić”, „miejscu nieprzyporządkowanym".
} 
Gdy mówią, że proletariat jest „produktem wielkiego przemysłu”, artykułują bezsens, pozostając w logice faktu dokonanego - reprodukcji proletariatu na szeroką skalę, a nie przygodnej logiki spotkania, która wytwarza (a nie powtarza), podobnie jak proletariat, tę masę wynędzniałych, wywłaszczonych ludzi, będących elementem procesu produkcji. Marks i Engels przechodzą od historyczno-przygodnej koncepcji trybu produkcji do ujęcia esencjalistycznego i filozoficznego (Althusser 2006, 198).

Dlatego należy uwolnić wyparty filozoficzny status nędzy, wywłaszczenia, nicości jako źródła wszelkiego procesu formacyjnego. Bieda, wywłaszczenie, wyzysk są punktem wyjścia do myślenia filozoficznego nie dlatego, że stanowią przedmioty lub tematy dla filozofów, ale dlatego, że praktyka i teoria zawdzięczają swą energię i moc właśnie swemu pierwotnemu wybrakowaniu w określone bycie. Są jak dziewiczy las równikowy, powiada Althusser.

„Podziemny nurt materializmu spotkania” bez watpienia wyprzedza swoje czasy. Próba oczyszczenia miejsca pustki, nicości i wywłaszczenia tkwi w samym sercu najważniejszych współczesnych trendów filozoficznych, które definiują się jako materialistyczne. Realizm spekulatywny na przykład w swoim poszukiwaniu niekorelacjonistycznego sposobu myślenia rozważa pojęcie absolutu, który nie jest „nasz”, który pozostaje na nas obojętny.

Otwarcie miejsca niedającego się ustalić w globalnym świecie, w którym miejsce wszystkiego jest już wyznaczone, nie ustanawiając go jednocześnie jako struktury transcendentalnej, stało się najważniejszym zadaniem etycznym i politycznym. To dlatego walczę ze soba, próbując uwolnić moją plastyczność z wszelkiego uścisku symbolicznego i nie dopuszczać do tego, by obejmowała nad czymkolwiek zwierzchnictwo.

To wszystko jest bardzo kruche, fale ciągle zalewają otwarte pola jednostkowości, niespodzianki, niespodziewanego doboru, rozpoznania zdolności, umiejętności przyjęcia nowych form, nawet jeśli nie były oczekiwane. Fale własności, przywłaszczania i reprodukcji wciąż zalewaja pierwotną deprywację ontologicznego bogactwa.

Dokąd zmierza materializm? To pytanie nigdy nie straci wieloznaczności. Aczkolwiek, jak powiada Darwin, gdy rozważamy zmienną naturę gatunków, mamy czasami wrażenie, że „budowa całego organizmu staje się jakby plastyczna”. Żyjmy dla tych czasów. 


\section{Wykaz literatury}

Althusser, Louis. 2016. „Podziemny nurt materializmu spotkania”. Tłum. J. Brzeziński. Praktyka Teoretyczna 1(19): 37-62.

Canguilhem, Georges. 1994. A Vital Rationalist: Selected Writings from Georges Canguilhem. New York: Zone Books.

Darwin, Karol. 2013. O powstawaniu gatunków droga doboru naturalnego, czyli o utraymywaniu sie doskonalszych ras w walce o byt. Tłum. S. Dickstein, J. Nusbaum. Oprac. J. Popiołek, M. Yamazaki. Warszawa: Wydawnictwa Uniwersytetu Warszawskiego.

Derrida, Jacques. 2016. Widma Marksa. Stan długu, praca żałoby i nowa Międzynarodówka. Tłum. T. Załuski. Warszawa: Wydawnictwo Naukowe PWN.

Hegel, Georg Wilhelm Friedrich. 1969. Zasady filozofii prawa. Tłum. A. Landman. Warszawa: PWN.

Jacob, François. 1973. Historia i driedziçność. Tłum. K. Pomian. Warszawa: Państwowy Instytut Wydawniczy.

Marks, Karol. 1976. „Przyczynek do krytyki heglowskiej filozofii prawa”. Tłum. [b.d.]. W Karol Marks i Fryderyk Engels. Drieła. T.1. Warszawa: Książka i Wiedza

Mrówka, Kazimierz. 2004. Heraklit. Fragmenty: nowy przeketad i komentar:. Warszawa: Wydawnictwo Naukowe Scholar.

Nietzsche, Fryderyk. 2016. Ecce homo. Jak sie staje, kim siejest. Tłum. J. Dudek, E. KireszturaWojciechowska. Kraków: vis-à-vis. 
Catherine Malabou - profesor filozofii na University of Kingston w Londynie i w ECS, Leuk-Stadt w Szwajcarii. Jest autorką kilkunastu książek, między innymi L'Avenir de Hegel (Vrin 1996), Les Nouveaux Blessés (Bayard 2007), Changer de différence (Galilée 2009) czy Avant demain. Épigenèse et rationalité (P.U.F. 2014). W języku polskim ukazała się jedna jej publikacja: Ontologia praypadtości. Esej o plastyczności destrukcyjnej (Fundacja Augusta Hrabiego Cieszkowskiego 2017).

\section{DANE ADRESOWE:}

Centre for Research in Modern European Philosophy

Kingston University

Penrhyn Road

Kingston upon Thames

KT1 2EE

Wielka Brytania

EMAIL: c.malabou@kingston.ac.uk

CYTOWANIE: Malabou, Catherine. 2018. „Dokąd zmierza materializm? Althusser/Darwin.“ Praktyka Teoretyczna 2(28): 16-29.

DOI: $10.14746 /$ prt.2018.2.1

\section{AUTHOR: Catherine Malabou}

TITLE: Whither Materialism? Althusser/Darwin

ABSTRACT: The author uses Althusser's materialism of the encounter to rethink Darwinism and the relation between natural and social selection. According to popular misinterpretation, social selection, or social Darwinism, implies constant fighting and competition as a foundation of society. Malabou argues that social selection (mis) understood that way is rather a disciplinary mechanism, preventing the emanation of difference within a system. This cliché ignores the ateological and contingent character of selection as well as the "plastic condition" of organisms in Darwin's theory, which we miss in contemporary social reality.

KEYWORDS: materialism, Darwin, Althusser, social selection, plasticity, form. 